\title{
O caso das Bruxas de Salem e a origem do plea bargaining norte-americano: contrapondo o entendimento dicotômico dos sistemas processuais penais
}

\author{
The Salem witchcraft and the origin of the north American \\ plea bargaining: contrasting the dichotomous knowledge \\ of the criminal justice systems
}

\begin{abstract}
Sarah Gonçalves Ribeiro ${ }^{1}$
Fundação Escola do Ministério Público do Estado do Paraná - Curitiba/PR, Brasil ribeirogsarah@gmail.com http://lattes.cnpq.br/1023020248431150

https://orcid.org/0000-0001-5573-2506

Rodrigo Régnier Chemim Guimarães ${ }^{2}$

Universidade Positivo - Curitiba/PR, Brasil rodrigo.chemim@up.edu.br http://lattes.cnpq.br/3509382891487960 https://orcid.org/0000-0001-7378-4553
\end{abstract}

Resumo: A questão que move o presente artigo é: pode o plea bargaining norte-americano ter sido originado por meios considerados pela doutrina contemporânea como predominantemente "inquisitórios"? Em caso afirmativo, e considerando que $95 \%$ dos casos naquele país se resolvem pelo plea bargaining, faz sentido seguir dizendo que o sistema processual penal dos Estados Unidos da América seja "acusatório"? E

1 Cursando pós-graduação e especialização de Direito na Fundação Escola do Ministério Público do Estado do Paraná, e, em Penal e Processo Penal na Universidade Curitiba. Graduada em direito na Universidade Positivo. Cursando filosofia na faculdade Claretiano.

2 Doutor em Direito de Estado pela Universidade Federal do Paraná. Professor Titular de Direito Processual Penal da Escola de Direito e do Programa de Mestrado Profissional em Direito da Universidade Positivo. Procurador de Justiça do Ministério Público do Estado do Paraná. 
mais: desconstruídos os rótulos que predominam na doutrina em torno desse tema, faz sentido insistir no emprego da dicotomia dos sistemas processuais penais, em acusatório versus inquisitório, notadamente na discussão da adoção de modelos processuais inspirados no plea bargaining norte-americano? Essas perguntas pretendem ser respondidas a partir da reconstrução histórica do plea bargaining nos Estados Unidos, o que remonta à sua colonização puritana, seu apego a disputas econômicas e às práticas introduzidas no século XVII, cuja expressão primitiva se encontra no famoso julgamento das "bruxas de Salem", em Massachussets. O artigo, então, explora como as coisas se deram nesse caso, identificando a semelhança entre os métodos utilizados no julgamento das bruxas de Salem e no moderno plea bargaining. A tortura física e psicológica, esta vinculada à possibilidade de duras penas, que atemorizavam os acusados de heresia nos processos da inquisição medieval, assim como a sua parca possibilidade de defesa, também foram encontradas nos julgamentos das bruxas de Salem. Assim, o que se percebe é que se perpetuou um modelo de justiça criminal tachado como "inquisitorial" pela transmissão cultural, como uma herança medieval em parcelas do processo penal norte-americano. Isso evidencia que não há rigidez conceitual acerca dos sistemas processuais penais contradizendo significativa parcela da doutrina contemporânea que segue se apegando à dicotomia inquisitório versus acusatório. E permite avançar para, desvinculando-se dessa amarração dicotômica doutrinária, que é própria das pretensões de organização científica do século XIX na Europa, e que de lá para cá vem promovendo uma visão dualista e que não aceita enxergar nada para além dos rótulos antagônicos de inquisitório ou acusatório, indagar se é conveniente, ou não e em que termos à luz da Constituição da República de 1988, adotar-se, no Brasil modelos inspirados no plea bargaining estadunidense.

Palavras-Chave: Plea bargaining; Inquisitório; Bruxas de Salem; Acusatório; Sistemas processuais penais.

ABSTRACT: The question that drives this article is: can the North American plea bargaining originate by means considered by contemporary doctrine as predominantly "inquisitorial"? If so, and considering that $95 \%$ of the cases in that country are resolved by plea bargaining, does it make sense to continue saying that the criminal procedure system in the United States of America is "adversarial"? And more: deconstructed the labels that predominate in the 
doctrine around this theme, does it make sense to insist on the use of the dichotomy of criminal procedural systems, in adversarial versus inquisitorial, notably in the discussion of the adoption of procedural models inspired by the American plea bargaining? These questions are intended to be answered based on the historical reconstruction of plea bargaining in the United States, which goes back to its Puritan colonization, its attachment to economic disputes and the practices introduced in the 17th century, whose primitive expression is found in the famous judgment of the "witches of Salem" in Massachusetts. The article then explores how things went in this case, identifying the similarity between the methods used in the Salem witches' trial and the modern plea bargaining. Physical and psychological torture, linked to the possibility of harsh penalties, which frightened those accused of heresy in the processes of the medieval inquisition, as well as their limited possibility of defense, were also found in the Salem witch trials. Thus, what can be seen is that a criminal justice model perpetuated as "inquisitorial" by cultural transmission has been perpetuated, as a medieval heritage in parts of the North American criminal process. This shows that there is no conceptual rigidity about criminal procedural systems, contradicting a significant part of contemporary doctrine that continues to cling to the inquisitorial versus adversarial dichotomy. And it allows us to move forward, detaching ourselves from this doctrinal dichotomous tie, which is typical of the pretensions of scientific organization of the 19th century in Europe, and which has since promoted a dualist vision and which does not accept to see anything beyond the antagonistic labels of inquisitorial or adversarial, to inquire whether it is convenient or not and in what terms, in light of the 1988 Constitution, to adopt models inspired by the American bargaining model in Brazil.

KeYwords: Plea bargaining; Salem witch trials; Inquisitorial; Salem witchcraft; Adversarial system.

SuMÁRIO: Introdução; 1. A baía de Massachussetts; 2. O julgamento das bruxas de Salem e o plea bargaining; Considerações Finais; Referências.

\section{INTRODUÇÃO}

Há certo paradoxo no trato do tema dos sistemas processuais penais na doutrina da atualidade. Não obstante exista uma pluralidade 
de classificações a esse respeito ${ }^{3}$, há um olhar dicotômico acentuado que apresenta os sistemas "acusatório" e "inquisitório", como antagônicos e incompatíveis. Mesmo quando o sistema jurídico do Estado apresenta características dos dois sistemas processuais penais, esses doutrinadores argumentam que, "apesar de eles não serem puros”, não podem ser mistos (pois aí seriam inconciliáveis). Assim, justamente o fato de não haver "pureza" entre eles justificaria a opção por um dos dois sistemas dentro do direito interno de cada Estado.

Analisando essa questão por outro contexto, entende-se que cada Estado possui o seu direito interno, ou seja, é, de fato, um equívoco tachar de "acusatório" ou "inquisitório" o direito que foi tradicionalmente oriundo dos usos e costumes de cada nação. Por exemplo: o Brasil, de colonização portuguesa, herdou o sistema civil law ${ }^{4}$, porém o direito interno brasileiro foi adequado aos seus usos e costumes, ou seja, em razão de suas particularidades culturais intrínsecas, o regramento positivado no Brasil não é exatamente o mesmo europeu. Após a independência de Portugal, não se implantou, no Brasil, um "sistema", pronto, "copiado e colado" do direito europeu. Ainda que diversas regras tenham sido importadas da Europa, desde o Império e, de forma mais destacada, também na Primeira República houve também um olhar para o direito norte-americano ${ }^{5}$.

3 Sobre o tema, Rodrigo Régnier Chemim Guimarães aponta quatorze formas diferentes de classificação dos sistemas "acusatório" e "inquisitório" na doutrina brasileira e estrangeira: GUIMARÃES, Rodrigo Régnier Chemim. A Atividade Probatória Complementar do Juiz como Ampliação do Contraditório e da Ampla Defesa no Novo Processo Penal Brasileiro. Tese. Curitiba: UFPR, 2015, pp. 246 e ss.

4 Sobre a divisão em "civil law" e "common law" vide, dentre outros: KELLY, John M. Uma Breve História da Teoria do Direito Ocidental. Tradução de Marylene Pinto Michael. São Paulo: Martins Fontes, 2010, pp. 233 e ss.; DAVID, René. Os Grandes Sistemas do Direito Contemporâneo. Tradução de Hermínio A. Carvalho. São Paulo: Martins Fontes, 2002, pp. 23 e ss.. Em particular sobre a influência da "civil law" fora da Europa, vide: GILISSEN, John. Introdução Histórica ao Direito. $4^{\mathrm{a}}$ ed., tradução de A.M. Hespanha e L. M. Macaísta Malheiros. Lisboa: Fundação Calouste Gulbenkian, 2003, pp. 206 e ss.

5 Vale anotar que o Decreto $\mathrm{n}^{\circ} 848$, de 11 de outubro de 1890 , que organizou a Justiça Federal, previu, em seu artigo 386, que "os estatutos dos povos cultos e especialmente os que regem as relações jurídicas na República dos Estados Unidos da América do Norte, os casos de common law e equity, serão também subsidiários da jurisprudência e processo federal" (BRASIL. Decreto n ${ }^{\circ} 848$, de 
À essa mistura de influências se somou a necessidade de realizar adaptações à realidade brasileira, promovendo-se ajustes, adaptações, criando estruturas jurídicas próprias, a exemplo da múltipla experiência dos Códigos estaduais, ou da manutenção da figura do Delegado de Polícia, no Código de Processo Penal de 1941, e, ainda, da forma inédita, em termos globais, de como se organizou o perfil e as funções do Ministério Público brasileiro na Constituição de 1988. Nessa mesma linha de compreensão, também serve de ilustração, no ponto que aqui se pretende explorar, ver como a introdução do modelo de plea bargaining ${ }^{6}$ norte-americano, que serviu de base para reformas legislativas de vários países europeus e latino-americanos (v.g. Itália, Alemanha, França, Argentina e Brasil), sofreu diferentes ajustes e adaptações em cada um dos países que nele se inspiraram 7 . De outra sorte, os Estados Unidos da América que foram colonizados, em grande parte, pelos britânicos, herdaram o sistema common law, ainda que seja possível identificar um direito interno norte-americano que foi estruturado desde o período da colônia ${ }^{8}$. O direito

11 de outubro de 1890. In: PIERANGELLI, José Henrique, Processo Penal: evolução histórica e fontes legislativas. Bauru: Jalovi, 1983, pp. 431-463).

6 Há diferentes modelos do que se pode denominar de plea bargaining. Para efeitos deste artigo se adota a referência abrangente dada por Regina Rauxloh, quando promoveu estudo comparativo entre o modelo norte-americano e o alemão. Em tradução livre: "Embora essas práticas possuam um grande número de formas em diferentes sistemas judiciais, elas compartilham em comum o fato de o réu renunciar a alguns direitos processuais criminais em troca de um tratamento mais brando pela a promotoria e pelo tribunal, com uma confissão trocada por uma redução de sentença geralmente no cerne da barganha". (RAU$\mathrm{XLOH}$, Regina. Plea Bargaining in National and International Law. New York: Routledge, 2014, p. 10).

7 Sobre o tema, vide: LANGER, Maximo. Dos Transplantes Jurídicos às Traduções Jurídicas: a globalização do plea bargaining e a tese da americanização do processo penal. Delictae, vol. 2, no 3, p. 19-115, julho-dezembro de 2017, p. 25.

8 "O direito inglês, proveniente dos processos da common law, é essencialmente um direito jurisprudencial (case law); suas regras são, fundamentalmente, as regras que se encontram na ratio decidendi das decisões tomadas pelos tribunais superiores da Inglaterra", e "a língua inglesa e o povoamento originariamente inglês dos Estados Unidos mantiveram este país na família da common law", não obstante, isso se trate "de uma observação geral, e desde que se enfoque mais de perto o problema, descobrem-se, entre o direito americano e o direito inglês, múltiplas diferenças de estrutura, algumas das quais são verdadeiramente substanciais e não podem ser ignoradas", conforme: DAVID, René. Os Grandes 
interno sofre constantes modificações para se adaptar às necessidades próprias de cada país, que variam devido a uma construção histórica e são essas mudanças que possibilitam demonstrar o equívoco que gira em torno da dicotomia dos sistemas processuais penais.

Nessa linha de compreensão, serve de exemplo para ilustrar o desencontro doutrinário, analisar o que se passa com o plea bargaining em termos de classificação teórica. Para alguns ele é a expressão máxima do que se costuma denominar de "sistema acusatório", pois seria representado por um modelo no qual as partes seriam as gestoras da prova, operando à luz do princípio dispositivo. Para outros, é de uma inquisitorialidade marcante, haja vista o exacerbado uso do poder pelo Estado que concentra os poderes de acusar e julgar nas mãos do promotor, e que opera, predominantemente, pela busca da confissão do investigado, por vezes, até chegando ao ponto de constranger psicologicamente o investigado a confessar para evitar uma sanção mais severa ${ }^{9}$. A impressão que passa é que, na análise dicotômica dos sistemas isso nada mais é do que um jogo de retórica.

Ana Lara Camargo de Castro, por exemplo, considera que o sistema "adversarial"10 é o pilar do direito penal norte-americano, e que o sistema de justiça penal nos Estados Unidos vive à sombra do júri “o que equivale a dizer que ele se orienta a partir do ideal constitucional, à espera desse confronto de opositores diante de membros imparciais da sociedade, mas, em realidade, resolve-se na quase totalidade por meio de pleas." ${ }^{11} \mathrm{Na}$

Sistemas do Direito Contemporâneo. Tradução de Hermínio A. Carvalho. São Paulo: Martins Fontes, 2002, pp. 408, 459 e ss.

9 No mesmo sentido a percepção de VASCONCELLOS, Vinícius Gomes de. Barganha do Processo Penal e o autoritarismo "consensual" nos sistemas processuais penais: a Justiça negocial entre a patologização do acusatório e o contragolpe inquisitivo. Revista dos Tribunais, 953, março de 2015, p. 261-279.

10 Sistema "adversarial" é considerado aqui como equivalente ao termo acusatório, em português. Não obstante alguns autores considerem que adversarial e acusatório seriam sistemas diferentes, a exemplo de Ada Pellegrini Grinover (GRINOVER, Ada Pellegrini. A Iniciativa Instrutória do Juiz no Processo Penal Acusatório. Revista Brasileira de Ciências Criminais. Ano 07, $\mathrm{n}^{\mathrm{o}} 27$, julho-setembro de 1999, pp. 71-79), a grande maioria trata as terminologias como sinônimas.

11 CAMARGO DE CASTRO, Ana Lara. Plea Bargain: resolução penal pactuada nos Estados Unidos. Belo Horizonte: D’Plácido, 2019, p. 25. 
mesma linha de raciocínio sobre o sistema "adversarial", Malcolm M. Feeley sustenta que a justiça negocial (incluindo o plea bargaining) se encontra em processo de expansão. ${ }^{12}$

Com o mesmo entendimento, Jacinto Nelson de Miranda Coutinho considera o plea bargaining "um instituto tipicamente do sistema acusatório, mormente daquele norte-americano." ${ }^{13}$ Seguindo a trilha, Aury Lopes Junior e Vitor Paczek, dizem que, um dos argumentos para implementar o plea bargaining no processo penal é que deve estar em conformidade com os princípios do modelo acusatório, e esclarecem que pelo Brasil possuir "cultura inquisitória" seria necessário recuperar o projeto de lei do novo Código de Processo que tramita por quase dez anos para que se possa "melhorar alguns aspectos e consagrar uma ampliação no nosso espaço negocial”, pois segundo eles, a negociação pode ser favorável ao processo penal desde que seja bem utilizada ${ }^{14}$. Ainda, Alafair S. Burke argumenta que "os promotores priorizam os casos, em parte, pela quantidade de paixão que sentem por cada um deles", e considera que esta dita "paixão" seria a "paixão acusatória", a qual, a seu sentir, "pode afetar o plea bargaining". ${ }^{15}$

Mas não foram todos os autores que ignoraram as incompatibilidades do plea bargaining com a ideia de um sistema acusatório. Há quem aponte as divergências, a exemplo do que se vê no estudo de John H. Langbein, no qual ele demonstra as diversas semelhanças entre os métodos utilizados no plea bargaining e nas inquisições europeias, trabalhando, portanto, na linha de considerar o instituto como inerente ao que se denomina, na visão dicotômica da doutrina, de "sistema inquisitório”. Fazendo coro a esse entendimento, Bernd Schünemann diz que o júri americano é ilusório, pois poucos têm acesso a ele e, na realidade, a

12 FEELEY, Malcolm M. Plea Bargaining and the structure of the criminal process. The Justice System Journal, v. 7, n. 3, p. 338-354, jan. 1982, p. 344.

13 MiRANDA COUTINHO, Jacinto Nelson de; MURATA, Ana Maria Lumi Kamimura. Plea bargaining à brasileira. Boletim Ibbcrim, $\mathrm{n}^{\circ} 317$, abril de 2019 , p. 04.

14 LOPES JR, Aury; PACZEK, Vitor. Plea Bargaining no projeto "anticrime": remédio ou veneno? In: GLOECKNER, Ricardo Jacobsen (org.). Plea Bargaining. São Paulo: Tirant Lo Blanch, 2019, p. 149-174.

15 BURKE, Alafair S. Persecutorial Passion, Cognitive Bias, and Plea Bargaining. Marquette Law Review, 183, vol. 91, Issue 1. Symposium: Dispute Resolution in Criminal Law, article 9, 2007, p. 192. 
esmagadora maioria da população é submetida a um modelo de processo inquisitório (ou seja: o plea bargaining). ${ }^{16}$

Ricardo Gloeckner vai além, pois apesar de considerar o plea bargaining como inerente ao sistema adversarial, diz que "no campo do direito processual penal, o plea bargain se encontra na origem do avanço do 'liberalismo autoritário"' ${ }^{17} \mathrm{Ou}$ seja, o autor identifica o instituto como um novo fenômeno autoritário (uma característica marcante que a doutrina costuma atribuir ao sistema inquisitório), que se mistura à filosofia política econômica e moral baseada na liberdade, com origem histórica norte-americana.

Como se vê, não há um entendimento acerca do instituto ser inerente ao sistema acusatório ou inquisitório. Muito pelo contrário, o que se demonstra é que cada autor cria a sua própria compreensão sobre o fenômeno do plea bargaining nos sistemas processuais penais. E talvez isso se deva pelo fato de que a amarração dicotômica dos sistemas, que boa parte da doutrina contemporânea insiste em usar, não encontra respaldo na realidade histórica ${ }^{18}$.

É certo que as transformações sociais dos oitocentos, alusivas à descoberta da lei e das codificações como instrumentos ordenadores, vinculadas, também, à afirmação do indivíduo e à simplificação da

16 SCHÜNEMANN, Bernd. Crítica al modelo norteamericano de processo penal. In: SCHÜNEMANN, Bernd. Obras. Tomo II. Colección Autores de Derecho Penal. DONNA, Edgardo Alberto (Director), Buenos Aires: RubinzalCulzoni Editores, 2009, pp. 427-450, p. 429.

17 GLOECKNER, Ricardo Jacobsen. Um "novo” liberalismo processual penal autoritário? In: GLOECKNER, Ricardo Jacobsen (org.). Plea Bargaining. São Paulo: Tirant lo Blanch, 2019, p. 177-190, p. 188.

18 Cite-se, por todos, a lição de CARBASSE, Jean-Marie. Histoire du droit penal et de la justice criminelle, $2^{a}$ editión refondue, Paris: Presses Universitaires de France, 2009, p. 216, tradução livre: "Nos últimos séculos do Ancien Régime, a palavra "prática" designará primeiro o processo (...) Assim, então, cada região, cada corte, por vezes cada tribunal, tinha seus próprios usos, isso que nós chamamos seu "estilo". É assim que na França do fim da Idade Média, o processo penal é muito pouco homogêneo, muito pouco claro, e, também, pouco "racional" o que se expõe nos tratados doutrinários. (...) O inquisitório e o acusatório coexistem ao longo de todo o século XIV e se interpenetram...". Para uma análise mais detalhada da impropriedade histórica da dicotomia acusatório versus inquisitório, vide: GUIMARÃES, Rodrigo Régnier Chemim. A Atividade Probatória Complementar do Juiz como Ampliação do Contraditório e da Ampla Defesa no Novo Processo Penal Brasileiro. Tese. Curitiba: UFPR, 2015, p. 229-380. 
demanda por justiça, promoveram um afastamento da concorrência de jurisdições nas quais havia se desenvolvido a "simbiose dualística entre accusatio e inquisitio", a ponto da análise se "cristalizar em dois tipos ideais de processos distintos e contrapostos”, como recorda Massimo Meccarelli ${ }^{19}$. Porém, também é certo que, no plano da construção teórica doutrinária de processo penal, esse dualismo igualmente decorre de uma pretensão de organização científica desenvolvida a partir do século XIX, notadamente a partir da obra de Giovanni Carmignani, "Teoria delle leggi della sicuritezza sociale", publicada em $1832^{20}$. Nela, Carmignani, que foi o primeiro autor europeu a trabalhar com a ideia de "sistemas processuais penais" ${ }^{21}$, sustentou ser possível identificar

19 MECCARELLI, Massimo. El proceso penal como lugar de determinación de la justicia. Algunas aproximaciones teóricas en la época del ius commune, In: GALAN LORDA, Mercedes (Directora), Gobernar y administrar justicia: Navarra ante la incorporación a Castilla. Navarra: Tompsom Reuters, Aranzadi, 2012, pp. 307-323, pp. 322-323.

20 Não obstante o discurso dos sistemas e da compreensão histórica do Direito tenha sido praticamente introduzido no início do século XIX, num primeiro momento, pela "Metodologia Jurídica” de Savigny (1802) e, num segundo momento, pela "jurisprudência dos conceitos" de Puchta (1832), apresentando o tema como "formas de procedimento judicial".

21 As palavras em latim, “accusatio" e “inquisitio", já eram empregadas nos textos romanos do Império (sobre o anacronismo de querer enxergar um sistema aqui, vide, dentre outros, RONCO. Alessandra. Il processo penale nella legislazione tardo imperiale. Tese. Universidade de Padova, Itália, 2008) e seguiram sendo adotadas ao longo dos tempos, mas não como "sistemas", nos moldes kantianos, isto é, como modelos de processo que partissem de uma ideia fundante e se organizassem por princípios unificadores. Ainda que alguns autores do início do século XIX tenham feito referências ao "processo inquisitório”, a exemplo de BIENER, Friedrich August. Beiträge zu der Geschichte des Inquisitionsprozesses und der Geschworenengerichte. Leipzig, 1827, passim, o primeiro a fazer isso, com pretensões de organização científica e invocando a ideia de sistemas processuais, foi CARMIGNANI, Giovanni. Teoria delle leggi della sicuritezza sociale. Tomo IV, Pisa: Fratelli Nistri, 1832, pp. 31-32, de cujo texto se extrai a seguinte esclarecedora passagem, em tradução livre: "Dois métodos entre os diversos para a pesquisa e demonstração do verdadeiro se apresentam ao espírito humano: o sintético, e o analítico. O primeiro é assertivo, e cabe admiravelmente à acusação, à qual o princípio político é sempre pronto; $o$ segundo é indagativo, e cabe admiravelmente à pesquisa que o princípio de justiça deseja. Um demonstra aquilo que acredita ser a verdade, o que o princípio político promotor do juízo penal sempre supõe, tem interesse de acreditar sempre e, quanto mais forte seja, mais facilmente converte o interesse em direito. $O$ outro 
um "sistema” a partir da seleção de trechos das práticas judiciárias ${ }^{22}$

rastreia, examina, separa as aparências da realidade, o errado do verdadeiro, e não o assinala senão ao final de uma lenta e cansativa viagem, o que o princípio de justiça já se manifestou ser o próprio voto. Um é um método de composição adaptado a quem se encarrega de apresentar um libelo de acusação. O outro é um método de invenção que poderia desejar-se para descobrir um tesouro escondido adaptado à situação de quem, com uma sentença, deve estabelecer uma verdade de fato e de direito. É, então, na índole do espírito humano, e é coerente à diversidade dos métodos de pesquisar ou de demonstrar uma verdade, a distinção do processo "accusatorio", assim chamado porque o acusador é quem o move e adere, e o processo "quesitorio" ou "investigatorio", assim chamado porque o juiz, com base em fundamentos prováveis, institui de ofício a pesquisa da verdade, ou do falso nas notícias que conhece, e que lhe chegam a partir de uma ofensa à segurança social. E também é, ao menos à primeira vista, inegável que isso proporcione, como critério de verdade, maiores garantias jurídicas do que aquele".

Aqui, Carmignani está se referindo às Practicae, próprias do século XIII. Sobre o tema, vide: GARLATI, Loredana. Per um storia del processo penale: le pratiche criminali. In: Rivista italiana di storia del diritto, vol. LXXXIX, 2016, pp. 71-109. As Practicae que são mais referidas pelos doutrinadores do século XIX são os textos de Alberto Da Gandino (GANDINUS, Albertus. Strafrecht der Scholastik. Von KANTOROWICZ, Hermann U., Berlin: J. Guttentag, 1907) e de Philippe de Beaumanoir, publicada em 1280 (BEAUMANOIR, Philippe de. Les Costumes de Beauvoisis. Nouvelle editión, publié d'aprés le manuscrits de la bibiotheque royale. Paris: Jules Renouard, 1842). Jean-Marie Carbasse também se refere à obra de Philippe de Beaumanoir, o qual, ao relatar os costumes da região de Clermont-en-Beauvoisis, na França, deu especial destaque ao modelo processual "híbrido", em que o juiz somente poderia iniciar um processo no caso de tê-lo presenciado (flagrante delito). (CARBASSE, Jean-Marie. Histoire du droit penal et de la justice criminelle, $2^{a}$ editión refondue. Paris: Presses Universitaires de France, 2009, p. 184). Em sentido similar, a lição de Massimo Valerani, em tradução livre: “A passagem da acusação à inquisição, seja de que forma for, é sempre vista como o sinal de uma estrutura judicial estadual completa. Trata-se, naturalmente, de um processo gradual, enquadrado em esquemas de evolução cronológica de diferentes padrões de tamanho. Com frequência se escolhem tempos longos, por vezes longuíssimos, do século XIII ao século XVIII, ou até mesmo do século XII ao XIX, depois de insistir numa evolução lenta e contrastada ou sob um ponto de ruptura preciso: a "Vergentis in senium" de Inocêncio III ou a Cruzada anticátara - termos "a quo" escolhidos em vários estudos sobre os procedimentos inquisitoriais anticlericais - ou mesmo o "Tractatus de maleficiis" de Alberto Gandino, que assinalaria a ruptura do monopólio da acusação privada, ou ainda os grandes processos políticos do início do século XIV que fossem de lesa majestade e de heresia, em um grande sistema penalístico-repressivo sem fronteiras”. E, sobre a obra de Alberto Da Gandino, Massimo Vallerani é ainda mais incisivo, dizendo (tradução livre): “...seu panfleto se alimenta principalmente das "questiones de facto" resolvidas de diferentes maneiras e em diferentes momentos pelos principais 
medievais do século XIII:

"Estas observações parecem confirmar que as probabilidades judiciárias formam um corpo de ciência; que nos livros dos práticos estão contidos os dados necessários a dar-lhes um sistema, e que não falta nada quando se queira diretamente decidir a sorte dos acusados, senão um trabalho, o qual coordenando regras esparsas, que nos livros dos práticos encontram-se jogadas as bases deste sistema científico, o qual não pode surgir todo de uma vez, mas pode, recolhendo progressivamente os casos decididos pelos seus verdadeiros caracteres, chegar um dia à sua maior perfeição". ${ }^{23}$

Como se vê no trecho acima, Carmignani "coordenou regras esparsas" para construir a ideia de sistemas acusatório e inquisitório, dizendo que ele "recolhia progressivamente os casos decididos pelos seus verdadeiros caracteres", visando, quem sabe, chegar "um dia à sua maior perfeição". Dali em diante, o que se encontra são cópias da apresentação feita por

juristas do século XIII, muitas vezes em contradição com os outros colegas e com ele mesmo. As "questiones" constituem, assim, um material perigoso, fundado na dúvida e num esquema dialético estruturalmente incapaz de estabelecer um sistema. Gandino faz uma série de escolhas conscientes, selecionando as opiniões que reforçam o seu sentido de "estado", mas esta seleção é confrontada com a natureza fragmentária e episódica de um "corpus" de opiniões baseadas em "casus". (VALLERANI, Massimo. Procedura e giustizia nelle città italiane del basso medioevo (XII-XIV secolo). In: CHIFFOLEAU, Jacques; GAUVARD, Andrea Zorzi (Organizadores). Pratiques Sociales et Politiques Judiciaires dans les Villes de L'Occident à la Fin du Moyen Age. Publications de l'École française de Rome, 2007, pp. 439-494). Mario Sbricoli analisando as práticas de Alberto da Gandino e outros da mesma época, também concorda com a mescla de modelos e com a dificuldade de aceitar a classificação dicotômica. Em tradução livre: “....antecipando uma classificação 'possível', sobre a qual retornarei, me parece ser necessário dizer que aqueles que nós percebemos, ou tendemos a 'ver', como dois modelos processuais distintos - o acusatório, o inquisitório - não aparecem, todavia, como 'modus procedendi' perfeitamente distintos. Trata-se de maneiras processuais diversificadas sob três distintos perfis, os quais, todavia, podem ser interligados entre eles no efetivo desenvolvimento do processo". (SBRICOLI, Mario. "Vidi Communiter Observari". L'emerzione di un ordine penale pubblico nelle città italiane del secolo XIII. In: Quaderni Fiorentini, XXVII. Centro studi per la storia del pensiero giuridico moderno. Firenze: Università degli Studi di Firenze, 1998, p. 268).

23 CARMIGNANI, Giovanni. Teoria delle leggi della sicuritezza sociale. Tomo IV, Pisa: Fratelli Nistri, 1832, p. 175, tradução livre. 
Carmignani, as quais aparecem com referência expressa, nas doutrinas de: Pessina ${ }^{24}$, Carrara ${ }^{25}$ e Mittermayer ${ }^{26}$, e, também, em alguma medida, nas obras de Faustin Hélie ${ }^{27}$, Adhemar Esmein ${ }^{28}$, e em praticamente todos os que se sucederam na análise dessa dicotomia. Assim se construiu, na doutrina europeia dos oitocentos, a ideia dos sistemas "puros" 29 , dicotômicos e antagônicos entre "acusatório" versus "inquisitório".

O que se percebe, então, é que falta, à doutrina contemporânea, compreender esse processo de mudança social que promove, no plano

24 PESSINA, Enrico. Storia delle leggi sul procedimento penale. Napoli: Dott. Pirro Pirrone Editore, 1912, p. 06-08.

25 CARRARA, Francesco. Programma del Corso di Diritto Criminale, Parte Generale. Vol. II, 9a ed., Firenze: Casa Editrice Libraria "Fratelli Cammelli", 1902, pp. 299 e ss.

26 MITTERMAIER, Carl Joseph Anton. Tratado da Prova em Matéria Criminal. Tradução para o francês da $3^{a}$ edição (1848), de C.A. Alexandre e para o português de Herbert Wüntzel Heinrich, Campinas: Bookseller, 1997, p. 33, nota 131; p. 34, nota 134; p. 35, nota 137; p. 36, nogta 142, p. 37, nota 144.

HÉLIE, Faustin. Traité de l'instruction criminelle ou Théorie du Code d'Instruction Criminelle. Premiére partie. Histoire et théorie de la procédure criminelle. Paris: Charles Hingray Libraire-Editeur, 1845.

ESMEIN, Adhemar. Histoire de la procédure criminelle en France: et speciélment de la procédure inquisitoire depuis le XIII siecle jusqu'a nos jours. Paris: L. Larose et Forcel Libraires-Editeurs, 1882.

O primeiro autor de processo penal a falar em "sistemas puros" foi Francesco Carrara, no segundo volume de seu famoso "Programma", dedicado ao estudo do processo penal (CARRARA, Francesco. Ob. cit., p. 319). No entanto, essa referência à pureza é falsa em termos históricos. Sobre o tema, vale a lição de Ettore Dezza, em tradução livre: "Na intervenção introdutória deste meu encontro entre historiadores do direito e estudiosos do processo penal, Michele Pifferi focouse no tema da relação entre os modelos acusatório e inquisitório, e oportunamente convidou a desconfiar das construções (e das reconstruções) excessivamente teóricas e abstratas: como historicamente nunca existiu (nem mesmo, podemos acrescentar, nas experiências de common law) um processo acusatório puro, assim como nunca existiu um processo inquisitório puro. Os eventos históricos do processo penal nos oferecem ao contrário um quadro articulado e composto, formado - como nos recorda Pifferi - por "contaminações, interferências, desperdícios e hibridações", numa contínua e oscilante alternância, de resto já claramente advertida e sinteticamente descrita por Felippo Maria Renanzi em 1777." (DEZZA, Ettore. Accusa e Inquisizione nell'Esperienza Italiana Contemporanea. In: NEGRI, Daniele e PIFFERI, Michele (org.) Diritti Individuali e Processo Penale nell'Italia Repubblicana. Materiali dall'incontro di studio Ferrara, 12-13 novembre 2010. Per la storia del pensiero giuridico moderno, 93, Milano: Giuffré Editore, 2011, p. 101-116). 
doutrinário, pretensões de organização científica do processo penal. $\mathrm{E}$ aqui se chega às questões que movem o presente artigo, no qual se procurará discutir se o plea bargaining norte-americano pode ter sido originado por meios considerados pela doutrina contemporânea como predominantemente “inquisitórios”. Em caso afirmativo, se procurará considerar se faz sentido seguir dizendo que o sistema processual penal dos Estados Unidos da América seja “acusatório”. E mais: desconstruído os rótulos que predominam na doutrina em torno desse tema, será avaliado se também faz sentido insistir no emprego da dicotomia dos sistemas processuais penais, em acusatório versus inquisitório, notadamente na discussão da adoção de modelos processuais inspirados no plea bargaining norte-americano. Até porque, é curioso que muitos considerem o sistema norte-americano como acusatório e ele se resolva, em 95\% dos casos, com a solução negociada nos moldes do plea bargaining ${ }^{30}$. E de um plea bargaining, registra-se, "à la americana", isto é, que funciona na medida em que o acusado se declara culpado e renuncia direitos básicos do processo para evitar o risco de penas mais elevadas, inclusive, a pena capital em alguns Estados daquele país. ${ }^{31}$

30 WATSON, Duncan. The Attorney General's Guidelines on Plea Bargaining in Serious Fraud: Obtaining Guilty Pleas Fairly? In: The Journal of Criminal Law. Vol. 74, Edição 1, p. 77-90, fevereiro de 2010, p. 78. Vide, também, a crítica de BARKOW, Rachel E. Separation of Powers and the Criminal Law. In: Stanford Law Review, Stanford, v. 58, n. 4, p. 989-1054, fev. 2006, p. 1033. Também é relevante a análise estatística progressiva apresentada por STITH, Kate. The Arc of Pendulum: Judges, Prosecutors, and the Exercise of Discretion. In: Yale Law School Legal Scholarship Repository, New Haven, $n^{\circ} 117$, p. 1420-1497, 2008, pp. 1453-1454, em tradução livre: "As Guidelines e a concomitantemente imposição de sentenças mínimas, teve outros efeitos significantes. Um dos mais notados foi a redução na frequência dos julgamentos federais. Antes das Guidelines, mais de 12\% dos acusados por crimes federais eram condenados mediante julgamento; até 1996, esta percentagem chegou a 8\%; e desde 2000 tem sido inferior a 5\%. De fato, durante o período 'compulsório' das Guidelines, declarações de culpa acabaram substituindo os julgamentos no sistema federal. Aqueles que estudaram esse fenômeno com razão dizem que isso decorre da 'adoção de novas leis a respeito de sentenças, que acabaram aumentando a influência do plea bargaining, em proveito dos prosecutors'.

31 ALSCHULER, Albert W. Plea Bargaining and Its History. Columbia Law Review. Vol. 79, nº 01, Jan 1979, p. 01. 
O ponto principal deste artigo, portanto, é demonstrar que não há uma rigidez conceitual nos sistemas processuais penais e isso será feito a partir da análise das raízes históricas do plea bargaining em território norte-americano. Quando a doutrina de processo penal fica amarrada à dicotomia "acusatório" versus "inquisitório", costuma dizer que o sistema norte-americano seria “acusatório”, porém, também há indícios que o plea bargaining tenha sido introduzido nos Estados Unidos pelos puritanos, em Massachussets, no século XVII, revelando-se no famoso caso das "bruxas de Salem" ${ }^{2}$, em modo de julgamento que, nessa mesma classificação dicotômica, seria tachado de "inquisitório". Neste ponto, vale anotar que apesar desse modelo negocial ter sido mais utilizado após a Guerra Civil americana, em $1865^{33}$, devido ao grande aumento da criminalidade que ocorreu junto ao deslocamento populacional em direção às regiões urbanas e imigração $0^{34}$, causando sobrecarga judiciária, há registros que antecedem esse momento, servindo o caso das bruxas de Salem de exemplo marcante e muito pouco explorado nessa discussão teórica em torno da classificação do sistema processual penal norte-americano.

Compreender como esse instituto surgiu e se desenvolveu nos Estados Unidos pode ser o ponto de partida para o abandono das categorias forçadas que não permitem enxergar para além delas mesmas. Essa amarração dicotômica e maniqueísta - ou o instituto é acusatório (e merece ser adotado) ou é inquisitório (e merece ser rechaçado) - não tolera que se avance para a construção de um melhor modelo de processo penal, adaptado à realidade e à Constituição brasileira, mantendo o país tanto numa discussão eurocêntrica em torno dos sistemas, quanto numa

32 Seria possível questionar se antes desse caso não tenha havido algum outro em moldes similares em território norte-americano, mas é o caso das "bruxas de Salem" que marca profundamente, na população daquele país, a percepção de que o uso da barganha pela confissão como modelo para evitar condenações à morte é uma opção a ser considerada, o que revela a importância histórica significativa na construção do plea bargaining nos Estados Unidos.

33 ALSCHULER, Albert W. Plea Bargaining and Its History. Columbia Law Review. Vol. 79, $\mathrm{n}^{\circ}$ 01, Jan 1979, p. 06.

34 George Fischer, no entanto, considera que existiram três ondas na adoção do plea bargaining, sendo que a primeira delas teria início apenas em 1920: FISCHER, George. Plea Bargaining's Triumph: a history of plea bargaining in America. Stanford, California: Stanford University Press, 2003, p. 06. 
disputa retórica a respeito do que se quer ou do que não se quer (por qualquer motivo, nem sempre declarado) para o processo penal brasileiro.

\section{A Baía de Massachussetts}

O caso das bruxas de Salem merece ser contextualizado para se compreender o grau de influência do poder, tanto religioso, quanto econômico, no desencadeamento das investigações, na condução dos processos e na adoção do modelo do plea bargaining.

Em meados do século XVI, na trilha da reforma protestante calvinista da Igreja Católica, cunhou-se, na Inglaterra, o termo "puritanismo", para designar as pessoas que desejavam se purificar dentro da Igreja Anglicana, sendo, posteriormente, interpretado como uma doutrina cristã. Por esses fiéis seguirem os ditames de Calvino, os adeptos do puritanismo desenvolveram um novo sistema de crenças que colocou em risco a herança feudal da época e acabou servindo aos interesses dos detentores do dinheiro ${ }^{35}$ - e, nessa medida, de parcela do poder -, pois Calvino justificava a riqueza terrena como algo querido por Deus ${ }^{36}$.

A principal característica desse grupo religioso era a graça da salvação e eles acreditavam que esta graça foi de forma divina destinada para um seleto grupo de pessoas, os eleitos, o que ocorria antes do seu nascimento. A virtude era o sinal da salvação e era encontrada na alma do puritano, por isso que as hierarquias, apesar de existentes, não eram úteis para determinar o valor divino, pois no céu não havia classe. Desta forma desenvolveram de forma diferenciada a ideia cristã de igualdade ${ }^{37}$.

Assim, considerando-se "escolhidos por Deus" os puritanos se rebelaram, separando-se da Igreja Anglicana e por medo de punições

35 GRIFFITHS, Megan Rose. Radicals, conservatives, and the Salem witchcraft crisis: Exploiting the fragile communities of colonial New England. Tese. Leiden University, 2017, p. 18.

36 DE BONI, Luis Alberto. Escritos Seletos de Martinho Lutero, Tomás Müntzer e João Calvino. Tradução de Ilson Kayser, Martin N. Dreher, Helberto Michel, Arno F. Steltzer e Sabatini Lalli. Petrópolis: Vozes, 2000; DELUMEAU, Jean. O Pecado e o Medo: A culpabilização no Ocidente (Séculos 13-18), vol. II. Tradução de Álvaro Lorencini, Bauru, SP: EDUSC, 2003, p. 371 e ss.

37 GRIFFITHS, Megan Rose. Op. Cit., p. 19. 
emigraram para a Holanda. Em meados de 1620, um pequeno grupo de puritanos, que ficou conhecido como peregrinos separatistas do Mayflower (nome do navio que os conduziu), embarcou para o território norte-americano para fundar a colônia de Plymouth ${ }^{38}$.

Uma década depois eles se juntaram a outro grupo de imigrantes puritanos, não separatistas, que desembarcou do navio Arbella, na baía de Massachussetts. Esse novo grupo insistiu em manter os dogmas reformadores da Igreja Anglicana e foi predominante por ter o respaldo oficial. Apesar dessa imigração não ter sido financiada pela Coroa Inglesa, mas sim por um grupo de empresários privados que buscavam lucrar com a expedição, a autoridade inglesa forneceu aos puritanos a "carta de patente para a Baía de Massachussetts"39, que não contou com a cláusula de competência para a Corte Londrina e foi entregue a John Winthrop e aos demais integrantes do grupo. ${ }^{40}$ Ao desembarcar na baía, fundaram a comunidade de Massachussets, que foi criada com base nas suas próprias crenças, na mesma trilha de acreditar ser o povo eleito por Deus para criar o novo Éden na Terra.

A colônia mais puritana, Massachussetts, tornou a condição de ser um membro da Igreja um pré-requisito para o comércio, o que a fez se diferenciar do restante das colônias da Nova Inglaterra, e, por decisão democrática a colônia concedeu o poder de legislar a Winthrop e seus assistentes no governo. ${ }^{41}$ Com a introdução de novas leis, iniciou-se um embate com os magistrados ingleses que não as respeitaram, pois agiam de forma conservadora. Para solucionar o conflito, buscou-se ajuda na Corte Geral da Inglaterra e, após diversas comissões, em 1647, foi aprovado um Código mais rígido, conhecido como The Lawes and Liberties of Massachusetts ${ }^{42}$. Dentre outras regras, o Código disciplinava que "Se

38 GRIFFITHS, Megan Rose. Op. Cit., p. 19-20.

39 A carta de patente para a Baía de Massachussetts, foi um documento entregue pela Coroa Inglesa que concedeu o domínio das terras em torno da Baía de Massachussets para os puritanos.

40 GRIFFITHS, Megan Rose. Op. Cit., p. 19-20.

41 SOUBBOTNIK, Michael A. Poder, autoridade e codificação das leis na "Cidade na Colina": a Baia do Massachusetts entre 1630 e 1648. Université Paris-Est -UPEM, 2013, vol.30, p.61.

42 SOUBBOTNIK, Michael A. Op. Cit., p.70. 
qualquer homem ou mulher for uma bruxa, isto é, tiver ou consultar um espírito familiar, eles serão mortos. Exod. 22. 18. Levit. 20. 27. Deut. 18. 10. 11." A bruxaria era considerada um dos "crimes capitais" e, para estes, era possível o emprego de tortura, após a condenação, visando alcançar outros partícipes do crime, assim regrado no mesmo Código: " $E$ ordenado, decretado e declarado por este Tribunal; que nenhum homem será forçado pela tortura a confessar qualquer crime contra si próprio ou outro, a menos que seja de crime capital onde ele seja condenado pela primeira vez por evidências claras e suficientes para ser culpado. Depois disso, se o caso for dessa natureza, é muito evidente que há outros conspiradores ou confederados com ele; então ele pode ser torturado, mas não com torturas tão bárbaras e desumanas." ${ }^{43}$

Os colonos impuseram à sociedade modelos de conduta, padrões e ideais de vida que representariam o caminho ideal a ser trilhado para alcançar e desfrutar da graça de Deus. Nesse modelo se incluía o trabalho árduo e bem-sucedido em qualquer ofício ou negócio por mais mundano que fosse, pois, tudo era enviado por Deus e enriquecer era atender ao chamado do divino. Com esta posição as divergências com as leis inglesas se destacaram ${ }^{44}$.

Apesar da questão religiosa que gira em torno da Nova Inglaterra, o vilarejo de Salem foi iniciado por interesse predominantemente agrícola e comercial, pois há uma rede de rios que desembocam em seu interior. Originalmente a localidade era conhecida apenas por "Salem Farm", que foi o nome coloquial designado ao responsável pelas questões agrícolas da comunidade. Após algum tempo, os fazendeiros passaram a divergir dos comerciantes, devido aos tributos que aumentaram, e, além disso, deixaram de fornecer alimentos à cidade. Esses conflitos proliferaram no período da secularização da colônia e, assim, era cada vez maior a mudança do agrícola para o mercantil, e os agricultores, que a princípio detinham o poder da vila, estavam perdendo o domínio do comércio. ${ }^{45}$

43 ESTADOS UNIDOS DA AMÉRICA. The Lawes and Liberties of Massachusetts. Online Library of Liberty, 1647, tradução livre. 
Em 1672, Salem Village passou a cuidar exclusivamente da atividade agrícola, separando-se da cidade, Salem Town, que ficou responsável pelo comércio ${ }^{46}$.

Os atritos entre Salem Town e Salem Village aumentaram com o passar do tempo, como relatam dezenas de petições, resoluções, depoimentos e protestos da época. Em 1667, por exemplo, o Tribunal de Essex registrou o pedido dos fazendeiros para deixar de fornecer homens para fazer a vigilância noturna em Salem Town, e apesar do Tribunal ter atendido à pretensão dos fazendeiros, a cidade manteve as exigências acerca do serviço. O Tribunal, num primeiro momento, deixou de determinar o cumprimento de sua decisão. ${ }^{47}$

Como o grupo de fazendeiros não possuía um aparato eclesiástico, tampouco Igreja, ministro ou capela, devido a obrigatoriedade de participar dos eventos religiosos eram compelidos, aos fins de semana, a viajar para a cidade. Foi nesse ponto que se potencializaram os impulsos separatistas na comunidade. Com a decisão do Tribunal finalmente se fazendo cumprir, permitiu-se a independência clerical e foram designados um ministro e a construção de uma Igreja em Salem Village. Ocorre que, Salem Town expediu também uma cobrança fiscal especial, aos fazendeiros, para arcar com as despesas da construção dessa capela. Assim, iniciaram-se diversos protestos e manifestos de recusa ao pagamento do tributo extra.$^{48}$ Dois fazendeiros, John e Thomas Putnan, ficaram responsáveis por levar o abaixo-assinado à cidade, porém o documento não foi recebido, nem mesmo após muita insistência. Essa e inúmeras outras rejeições semelhantes provaram que a cidade de Salem era hostil aos seus interesses. ${ }^{49}$

A instabilidade da situação da comunidade de Salem Village contribuiu, e muito, para acentuar as brigas internas e a desordem na região. Segundo Jeremiah Watt, morador da vila, esse desfecho caracterizou a comunidade como aquela em que: "irmão é contra o seu irmão e os vizinhos são contra os seus vizinhos, pois todos brigam e ferem uns aos outros". ${ }^{50}$

$\begin{array}{ll}{ }_{46} & \text { BOYER, Paul. NISSENBAUM, Stephen. Op. Cit., p. 17-18. } \\ 47 & \text { BOYER, Paul. NISSENBAUM, Stephen. Op. Cit., p. } 40 . \\ 48 & \text { BOYER, Paul. NISSENBAUM, Stephen. Op. Cit., pag. } 40 . \\ { }^{49} & \text { BOYER, Paul. NISSENBAUM, Stephen. Idem. } \\ { }^{50} & \text { BOYER, Paul. NISSENBAUM, Stephen. Op. Cit., p. 45-46. }\end{array}$ 
O ocorrido com o ministro James Bayley foi o estopim dos conflitos. Ele iniciou seu trabalho, em Salem Village, em outubro de 1672. Já no ano seguinte foi chamado para uma reunião entre os chefes de família do local, ocasião em que foi presenteado por cinco fazendeiros com quarenta acres de terra, em área nobre, para construir a sua residência. Porém, no mesmo ano se verificaram os primeiros sinais de descontentamento com o seu ministério, quando quatorze membros atrasaram o pagamento dos impostos com o apoio do ministro. ${ }^{51}$

Em 1679, algumas pessoas da comunidade de Salem Village, lideradas por Nathaniel Putman, e Bray Wilkins, se voltaram contra Bayley que convocou, em seguida, uma reunião para reconhecer as divergências e enfatizar que iria se comprometer ainda mais com o seu trabalho. Após diversos conflitos com o ministro, foi feito um apelo para a Igreja de Salem Town para que ela os ajudasse a resolver as controvérsias. Em abril do mesmo ano, o ministro da cidade, John Higginson, enviou uma carta ao conselho de Salem Village favorecendo a Bayley e aconselhando os moradores da região a se submeter ao comando do ministro ${ }^{52}$.

O ministro Bayley, meses depois, em julho, informou aos moradores que pretendia sair do cargo, o que potencializou os conflitos. Além disso, foram enviadas ao Tribunal inúmeras petições externando a revolta das pessoas. Em resposta, a câmara redigiu um decreto que ordenava que: "o Sr. Bayley continuasse no cargo e se estabelecesse como o ministro daquela região". Somou-se a isso, o alerta da cidade aos moradores de Salem Village para que os impostos fossem pagos corretamente e caso houvesse irregularidade haveria consequência. Esta ameaça deixou transparecer os interesses políticos na questão e foi o ponto principal para desencadear o "surto de bruxaria" de 1692.

Após a saída de três dos ministros designados para Salem Village a comunidade se tornou instável e distante da tão esperada independência. O novo ministro, Samuel Parris, em meados de 1691, identificou publicamente alguns dos moradores como seus inimigos ${ }^{53}$.

\footnotetext{
51 BOYER, Paul. NISSENBAUM, Stephen. Op. Cit., p. 46.

52 BOYER, Paul. NISSENBAUM, Stephen. Idem.

53 BOYER, Paul. NISSENBAUM, Stephen. Op. Cit., p. 60.
} 
Com esses intensos conflitos se formaram dois grupos na região de Salem Village: os a favor e os contra Parris. Esse é o pano de fundo para o que viria em seguida: o surto das bruxas de Salem, em 1692, decorrência da intensidade com que se vivenciou o aumento da vingança entre os locais ${ }^{54}$.

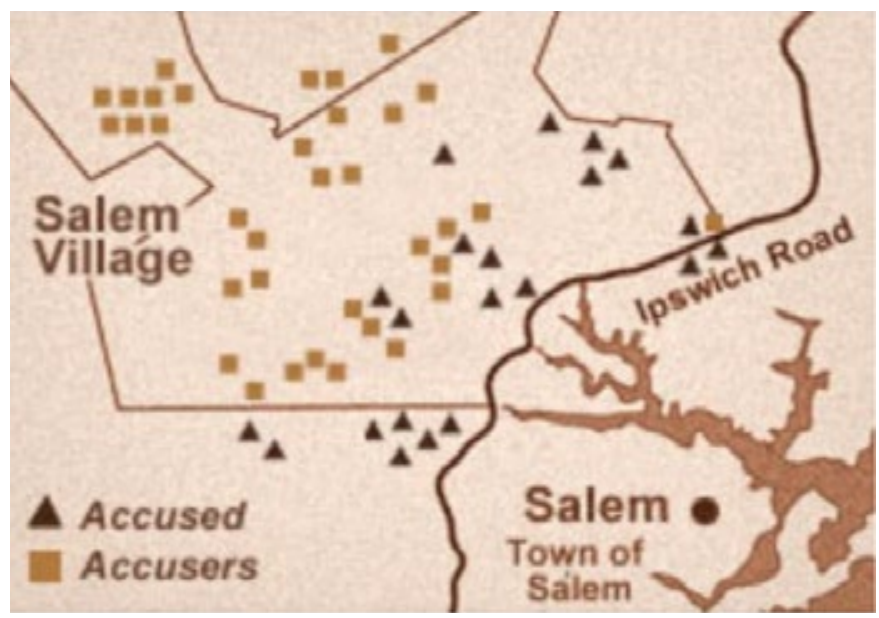

Discovery Education

\section{O julgamento das bruxas de Salem e o plea bargaining.}

Na pequena comunidade de Salem Village meninas jovens se reuniam para conversar a respeito do futuro e, ocasionalmente, criaram uma "bola de cristal", bastante primitiva, feita com uma clara de ovo que ficava suspensa em um copo que flutuava ${ }^{55}$.

Em fevereiro de 1692, os pais destas meninas externaram em palavras o que estava ocorrendo com as suas filhas, como sendo

\footnotetext{
54 BOYER, Paul. NISSENBAUM, Stephen. Op. Cit., p. 65.

55 BOYER, Paul. NISSENBAUM, Stephen. Op. Cit., p. 01.
} 
"comportamento estranho". Como os ânimos estavam acirrados, foi o suficiente para dar início ao que se denominou como o "surto das bruxas" ${ }^{56}$.

A princípio, tentou-se contornar a situação de maneira silenciosa, até que o ministro Parris resolveu tomar uma postura a respeito da situação e chamou o médico local, para tratar a sua filha, Betty Parris, de nove anos, e a sua sobrinha, Abigail Willians, de onze anos, que sofriam de convulsão. O doutor, Griggs, não alcançou um diagnóstico: "não consigo identificar o comportamento delas", e então, o posicionamento foi que elas poderiam estar possuídas por um demônio. Assim, não se tratava de doença, mas sim, de um crime cometido contra estas jovens meninas ${ }^{57}$, ou seja, alguém as havia enfeitiçado e deveria ser investigado para que se pudesse punir o culpado.

Posteriormente, mais oito meninas, incluindo três da família Putman, também foram "afetadas", apresentando marcas de machucados pelo corpo, o que deixou a comunidade em estado de alerta máximo. E, por fim, no dia 29 de fevereiro de 1692, após longo questionamento e conversa com essas meninas, consideradas "vítimas de bruxaria", elas apontaram três nomes e foram expedidos mandados de prisão em face de: Sarah Good, Sarah Osborne e uma escrava, índia, chamada Tituba, acusadas de "bruxaria" 58 . Os registros dos depoimentos da época deixam transparecer, ao menos naquele de Sarah Good, uma pressão para confessar. Ela é perguntada a respeito de seu conhecimento dos espíritos malignos, se fez um pacto com o diabo, e se machucou as meninas, no que ela responde negativamente. As meninas, então, são chamadas à frente de Sarah Good e apontam para ela como uma das pessoas que as machucaram. O interrogador, então, retoma a palavra e diz: "Sarah Good você não vê agora o que você fez? Porque você não nos conta a verdade? Por que você causou tormentos nessas pobres crianças?" Pressionada, Sarah Good acusou Sarah Osborne de ter machucado as crianças. Sarah Osborne negou

56 BOYER, Paul. NISSENBAUM, Stephen. Idem. York: Cambridge University Press, 2014, p. 125. 
as práticas de bruxaria, no entanto a escrava Tituba confessou, dizendo que "o diabo veio até ela e a obrigou a lhe servir". Acrescentou, ainda, que quatro mulheres e um homem machucavam as crianças, dentre elas Sarah Osborn e Sarah Good e disse que eles lhe obrigaram a também lesionar as crianças, caso contrário ela seria machucada por eles. A escrava prestou dois depoimentos e revelando atender ao que os interrogadores queriam ouvir, disse ter visto gatos pretos e vermelhos os quais lhe arranharam porque ela não queria servir aos seus propósitos de machucar as crianças. Sempre induzida pelas perguntas, ia confirmando tudo o que lhe perguntavam, chegando a confessar ter firmado um contrato por escrito com o diabo, se dizendo muito arrependida ${ }^{59}$.

Com a confissão da escrava, o aparelho governamental que provocou a histeria das bruxas também criou rígidos critérios, que podem ser classificados, nos termos da dicotomia doutrinária de processo penal, como "inquisitoriais", para salvar a vida dessas mulheres acusadas de bruxaria: elas deveriam confessar e delatar seus cúmplices para que fossem poupadas da forca. ${ }^{60}$

Acreditava-se, na época, que a bruxa da Nova Inglaterra era uma pessoa com poderes sobrenaturais, através dos quais fazia mal as pessoas $^{61}$. A confissão da escrava Tituba convenceu o povo da colônia que esta prática de bruxaria não se tratava de um caso isolado. O fato dela ter sido uma escrava, pode ter influenciado na sua confissão, pois não prestigiava de posição social e o pedido por clemência poderia ser a única forma de poupar a sua vida, e de fato, foi o que ocorreu ${ }^{62}$. Ela permaneceu encarcerada durante um período e ao se submeter ao Grand

59 ROSENTHAL, Bernard (General Editor). Examinations of Sarah Good, Sarah Osburn, \& Tituba, as Recorded by Ezekiel Cheever. In: Records of the Salem Witch-Hunt. New York: Cambridge University Press, 2014, pp. 127 e ss.

60 MORAIS, Gabriela de Souza. Os processos de Salem: uma breve análise da sua historiografia, memórias e representações. Curitiba: Cadernos de Clio, 2015, p. 152.

61 ROSENTHAL, Bernard (General Editor). General Introduction. In: Records of the Salem Witch-Hunt. New York: Cambridge University Press, 2014, p. $15-16$.

62 CONDÉ, Maryse. Eu, Tituba - bruxa negra de Salem. Rio de Janeiro: Rosa dos Tempos, 2019, p. 55 (kindle). 
Jury (júri de acusação) teve sua acusação recusada ("ignoramus") em 9 de maio de $1692^{63}$.

No dia 21 de maio de 1692, foi feita uma denúncia por Thomas Putnan e John Putnan, contra Susannah Roots. Segundo eles, ela teria praticado diversos atos de bruxaria nos corpos de Mary Wallcott, Abigal Williams, Marcy Lewis, Ann Putnan e outras meninas ${ }^{64}$.

A primeira a ser julgada pelo Tribunal foi Bridget Bishop que se declarou tão inocente "quanto uma criança que acabara de nascer" e no dia 10 de junho de 1692 foi executada na forca. Este modelo se repetiu com todas as acusadas que se negaram a confessar. ${ }^{65}$

O julgamento de Rebeca Eames, foi em 1692. Ela foi acusada de praticar feitiçaria e, inicialmente, confessou a sua culpa, pediu perdão ao senhor e prometeu obediência a ele pelo resto da sua vida. Depois, negou os fatos e foi condenada à forca ${ }^{66}$, pois, segundo os juízes: "o diabo te batizou, encontrou o seu corpo e fez de você uma bruxa" ${ }^{67}$.

O julgamento de Abigail Hobbs, torna-se interessante na compreensão da adoção de um modelo equivalente ao moderno plea bargaining, pois demonstra o momento que as pessoas acusadas de serem bruxas perceberam que, por mais que fossem inocentes, negar as acusações as levaria à morte, e, confessar e suplicar pelo perdão, seria a única chance de poupar as suas vidas. Ela havia sido condenada à morte na forca ${ }^{68}$, suplicou pelo perdão e "ofereceu a sua vida como expiação de seu pecado".

63 ROSENTHAL, Bernard (General Editor). Indictment of Tituba, for Covenanting (Returned Ignoramus). In: Records of the Salem Witch-Hunt. New York: Cambridge University Press, 2014, p. 820.

64 BOYER, Paul. NISSENBAUM, Stephen. The Salem Witchcraft Papers: Verbatim Transcripts of the Legal Documents of the Salem Witchcraft Outbreak of 1692.

65 BROOKS, Rebecca Beatrice. History of the Salem witch trials. In: History of Massachusetts, 2011.

66 ROACH, Marilynne. The Salem Witch Trials. A day-by-day chronicle of a Community under siege. New York: Taylor Trade Publishing, 2004, p. 294.

67 WOODWARD, W. Elliot. Records od Salem witchcraft - copied from the original documents. Vol. II. Roxbury, Massachussets: Privately printed for W. E. Woodward, 1864, pp. 143-146.

68 ROACH, Marilynne. The Salem Witch Trials. A day-by-day chronicle of a Community under siege. New York: Taylor Trade Publishing, 2004, p. 295. 
Após ser perdoada, as outras mulheres acusadas de bruxaria e que estavam no corredor da morte seguiram seu exemplo, ou seja, "as demais supostas bruxas também começaram a confessar". ${ }^{9}$

O certo é que se espalhou entre os envolvidos a ideia de que a confissão serviria de mote para o posterior perdão, evitando a forca. A pressão psicológica pela confissão ficou bem demonstrada no caso ocorrido em janeiro de 1693, envolvendo seis mulheres acusadas de bruxaria: Mary Osgood, Mary Tyler, Deliverance Dane, Abigail Barker, Sarah Wilson Sr. e Hannah Tyler. Havia uma crença, na época, de que, em casos de bruxaria, pessoas doentes podiam sentir quem eram os culpados pela sua doença, quando essas pessoas delas se aproximassem. E isso servia como uma "prova espectral". Um casal da cidade de Andover, vizinha de Salem, Joseph Ballard e sua esposa, estavam doentes e, por alguma razão que não consta dos documentos da época, as seis mulheres foram trazidas, vendadas, à presença do casal, sendo instadas a tocar-lhes com as mãos. Ao sentir a presença das seis mulheres, o casal as acusou de bruxaria, dizendo que estavam bem e se sentiram mal na presença delas. As mulheres foram presas e quando apresentadas ao Grand Jury, prestaram o seguinte depoimento, assim registrado nos documentos da época:

"Então, todas nós fomos capturadas, como prisioneiras, por um mandado do Juiz de Paz e imediatamente transportadas para Salem. E, devido a essa súbita surpresa, por nos conhecermos completamente inocentes desse crime, ficamos todas extremamente atônitas e espantadas, e consternadas e aterrorizadas, mesmo fora de nossa razão; e nossas relações mais próximas e mais queridas, vendo-nos nessa condição terrível e conhecendo nosso grande perigo, compreenderam que não havia outra maneira de salvar nossas vidas, já que o caso havia sido circunstanciado, senão confessando-nos ser tais e tais pessoas como os afetados nos representavam ser, eles, por ternura e piedade, nos convenceram a confessar o que confessamos. E, de fato, essa confissão, como se diz que fizemos, não era outra senão o que nos foi sugerido por alguns senhores, eles nos disseram que éramos bruxas, e que eles sabiam disso, e sabiam disso, e sabiam disso, o que nos fez pensar que era assim;

69 UPHAM, Caroline E. Idem. 
e nossos entendimentos, nossa razão, nossas faculdades quase desapareceram, não fomos capazes de julgar nossa condição; assim como as duras medidas que eles usaram conosco nos tornaram incapazes de fazer nossa defesa, apenas dissemos tudo e qualquer coisa que desejavam, e a maior parte do que dissemos, foi, na verdade, um consentimento do que eles disseram. Algum tempo depois, quando estávamos mais bem compostas, eles nos dizendo o que havíamos confessado, professamos ser inocentes e ignorantes de tais coisas; e ouvimos que Samuel Wardwell havia renunciado à sua confissão e, rapidamente, depois teria sido condenado e executado, e assim disseram que algumas de nós estávamos indo atrás de Wardwell."70

Esse registro histórico é marcante de como operava a pressão pela confissão na época, ainda mais diante do medo da forca. Além da confissão evitar a morte, a recusa em confessar poderia levar à tortura, como se deu no caso de Giles Corey, um agricultor com má fama na comunidade, pois os Putman acreditavam que ele era envolvido com negócios ilegais. A sua reputação piorou após espancar Jacob Goodale, um trabalhador rural, até a sua morte, em 1676, e para ajudar na trama ele foi viúvo por três vezes. No dia 21 de março de 1692, a sua esposa Martha Corey, foi acusada de bruxaria, e ele por estar envolvido com os casos de bruxaria, a princípio acreditou, e inclusive, testemunhou contra a sua esposa, dizendo que seu boi e seu gato tiveram uma súbita doença e, além disso, disse que a sua esposa ficava até tarde da noite ajoelhada em frente à lareira fazendo orações. ${ }^{71}$

No dia 18 de abril de 1692, foi expedido um mandado de prisão contra Giles Corey, que havia sido acusado de realizar bruxaria por Ann Putnan Jr., Mercy Lewis, Abigail Williams, Mary Walcott e Elizabeth Hubbard. No julgamento de Corey, ele negou a prática de bruxaria e os juízes John Hathorne e Jonathan Corwin o acusaram diversas vezes de

70 ROSENTHAL, Bernard (General Editor). Declaration of Mary Osgood, Mary Tyler, Deliverance Dane, Abigail Barker, Sarah Wilson Sr., \& Hannah Tyler. In: Records of the Salem Witch-Hunt. New York: Cambridge University Press, 2014, p. 738, tradução livre.

${ }_{71}$ BROOKS, Rebecca Beatrice. Idem. 
mentiroso, inclusive, no Tribunal, as mãos de Corey foram amarradas, como demonstrou os registros do ministro Samuel Parris ${ }^{72}$ :

"Então o tribunal ordenou que suas mãos fossem atadas.

Magistrado: Não é suficiente agir com bruxaria em outros momentos, mas você deve fazê-lo agora diante da autoridade?

Corey: Sou uma pobre criatura e não posso evitar.

Com o movimento de sua cabeça novamente, eles tiveram suas cabeças e pescoços aflitos.

Magistrado: Por que você mente para as testemunhas que te ouviram falar dessa maneira, nesta mesma manhã?

Corey: Eu nunca vi nada além de um porco preto".

Na tentativa de obter informações do acusado, o Tribunal apresentou o testemunho que ele havia feito contra a sua esposa, porém, ele se recusou a fornecer qualquer informação. Seu julgamento nunca chegou ao fim, pois faleceu sendo torturado, pelo Xerife Corwin, em setembro de $1692 .^{73}$

O caso de Corey também deixa evidenciado que as pessoas que se recusavam a prestar informações eram torturadas, não obstante a lei da época só admitisse formalmente a tortura para os condenados a fim de entregar seus cúmplices. Além disso, como demonstrado acima, as supostas bruxas que se declaravam inocentes eram condenadas à morte, como o caso de Bridget Bishop, mas quando elas confessavam o crime e se declaravam culpadas de todas as acusações, elas eram perdoadas, permaneciam um tempo em cárcere e logo após retornavam aos seus lares. No caso, se fosse invocar a dicotomia dos sistemas processuais penais, caberia dizer que, no julgamento das bruxas de Salem se evidenciou os primeiros sinais de plea bargaining como um modelo processual penal muito mais voltado para o rótulo de "inquisitório" do que de "acusatório".

\footnotetext{
72 BROOKS, Rebecca Beatrice. Idem.

73 BROOKS, Rebecca Beatrice. Idem.
} 
Apesar das condenações e execuções de bruxaria no restante da Europa estarem relacionadas a mulheres de baixa renda e sem posição social de destaque, assim como Tituba, na Nova Inglaterra ocorreu de forma diferente, pois o escândalo de bruxaria atingiu pessoas consideradas da alta sociedade e desse modo, evidenciou-se que a questão era mais política e econômica do que apenas religiosa. ${ }^{74}$

Em outubro de 1692, foi aprovada a lei que proibia o uso de "evidência espectral" como prova e, consequentemente, as pessoas acusadas de serem bruxas passaram a ser perdoadas por falta de prova. ${ }^{75} \mathrm{O}$ Tribunal responsável pelo julgamento das bruxas de Salem foi encerrado em maio de 1693 , tendo investigado 162 pessoas, das quais 52 foram processadas, 30 condenadas à morte e 20 executadas. Cinco delas morreram na cadeia ${ }^{76}$.

Após o fim do julgamento das bruxas, os crimes cometidos no Tribunal deixaram a população de Salem com sentimento de culpa. Em 1697, o então governador, Stoughton, emitiu uma nota de esperança em busca do perdão de Deus, e assim, o dia 15 de janeiro de 1697 ficou conhecido como: o Dia da Humilhação Oficial. ${ }^{77}$

Como visto, nesses registros dos julgamentos das bruxas de Salém é possível evidenciar os primeiros sinais, em território norte-americano, do modelo que hoje se conhece por plea bargaining. ${ }^{78}$ Naquele nascedouro do que viria a se tornar os Estados Unidos da América, quando as mulheres acusadas pelo crime de bruxaria admitiam a culpa, eram poupadas da forca e a pena era substituída pelo cárcere seguido da soltura, já as que negavam o "delito", eram executadas ${ }^{79}$.

Os crimes cometidos no julgamento de Salem traumatizaram a população da época e, com isso, "há relatos que indicam que, por tempo, os Tribunais anglo-americanos não incentivaram as admissões de culpa, $e$

74 MORAIS, Gabriela de Souza. Op. Cit., p. 152.

75 BROOKS, Rebecca Beatrice. Op. Cit., p. 149-150.

${ }^{76}$ ROACH, Marilynne K. Six Women of Salem. The untold story of the accused and their accusers in the Salem Witch Trials. Boston: Da Capo Press, 2013, p. IX.

77 BROOKS, Rebecca Beatrice. Idem.

78 LEVISON, David. Encyclopedia of crime and punishment. Thousand Oaks, California: Sage, 2002, p. 1148.

79 LEVISON, David. Idem. 
com frequência desencorajavam esta prática." ${ }^{80}$ Além disso, o historiador Alschuler, concluiu que: "há registros criminais americanos, do início do século XIX, que revelam uma taxa extremamente baixa de condenações. Essa prática de desencorajamento da admissão de culpa persistiu até a metade desse mesmo século, pois surgiu a figura mais ativa do promotor de justiça nos casos criminais. ${ }^{" 11}$ E posteriormente, após muita resistência dos Tribunais, eles passaram a admitir a barganha como uma prática legal nos Estados Unidos.

O primeiro registro, dessa nova tentativa, de plea bargaining norte-americano foi em 1804, período pós independência, curiosamente em Massachussets $^{82}$. John Battis, um negro de vinte anos de idade, declarouse culpado (plea guilty) da acusação de homicídio de uma menina, pele branca, de 13 anos de idade. ${ }^{83} \mathrm{O}$ magistrado do Tribunal, informou-o sobre o seu direito de permanecer em silêncio e também de negar qualquer uma das acusações que lhe foram imputadas. Mas Battis, insistiu em se declarar culpado de todas as acusações. ${ }^{84}$

Os norte-americanos do vilarejo de Salem, sem ter a dimensão exata do que faziam, no seio de uma situação volátil e perigosa, acabaram induzindo, culturalmente, a criação de um sistema de justiça criminal, ${ }^{85}$ de molde muito mais ajustado ao rótulo de "inquisitorial" e que ainda hoje é responsável por aproximadamente 95\% das condenações nos Estados Unidos da América.

O estudo realizado por John Harris Langbein, sobre as semelhanças dos métodos coercitivos exercidos no plea bargaining e na inquisição medieval, confirma a hipótese de, nos termos da dicotomia doutrinária, ser catalogado como "inquisitório" aquele instituto.

Segundo Langbein, a barganha é utilizada como instrumento de negociação no plea bargaining entre o promotor e o acusado. Com uma

\footnotetext{
80 ALSCHULER, Albert. Op. Cit., p.5.

81 ALSCHULER, Albert. Idem.

82 ALSCHULER, Albert. Op. Cit., p. 09.

83 ESTADOS UNIDOS. United States - Mass, 95 (1804), Commonwealth v. Bettis. In: Caselaw Acess Project. Harvard Law School.

84 Idem.

85 BROOKS, Rebecca Beatrice. Op. Cit.
} 
vantagem sobre o acusado, o agente público o induz a confessar a sua culpa e renunciar os seus direitos a um julgamento em troca de atenuação da pena, ou seja, há uma clemência por parte do promotor de Justiça na redução da pena e convencimento do juiz para homologação do acordo. ${ }^{86}$

Para ele, as semelhanças entre os métodos coercitivos utilizados pelo promotor do plea bargaining nos Estados Unidos e do inquisidor medieval são significativas e o principal paralelo entre eles é o uso da confissão como único meio de prova. Da mesma forma ambos buscam induzir o juiz a realizar a mesma apreciação apresentada e os acusados nos dois processos renunciam aos seus direitos. A similitude entre estas instituições reside no fato do país norte-americano ter substituído a tortura por sentenças que impõem penas elevadíssimas, inclusive de morte, e é neste ponto que a barganha se torna semelhante à tortura coercitiva. ${ }^{87}$

"Obviamente há uma diferença entre ter seus membros esmagados ou sofrer alguns anos extras de prisão se você se recusar a confessar, mas a diferença é de grau, não de tipo." 88

Analisando essas situações, nota-se que, em uma o acusado confessava por medo de ser submetido à tortura, já na outra, o acusado confessa por medo de ficar muito mais tempo na prisão ou ser morto. ${ }^{89} \mathrm{O}$ mesmo ocorreu no julgamento das bruxas de Salem: as pessoas acusadas de serem bruxas confessavam por medo da forca.

Neste contexto, caso se siga insistindo em invocar a dicotomia dos sistemas processuais penais, nitidamente, deve-se dizer que os Estados Unidos da América possuem um sistema predominantemente "inquisitório" e não "acusatório" como diz a maioria dos doutrinadores, pois uma vez que o plea bargaining corresponde a cerca de $95 \%$ dos casos, não parece sensato afirmar que esses $5 \%$ torne algo prevalente ou seja representativo do seja o seu sistema processual.

\footnotetext{
86 LANGBEIN, John H. Torture and Plea Bargaining, The University of Chicago Law Review, Chicago, v. 46, n. 3, 1978, p. 03-22. 
Em verdade, essa questão toda permite tornar mais evidente que essa disputa classificatória entre "acusatório" e "inquisitório", parece ser um erro teórico que se perdura por gerações. Melhor do que o rótulo de um e de outro é saber se o instituto atende às premissas de orientação do direito interno de cada país. Por exemplo, a Constituição da República brasileira de 1988, deixa anotada uma dupla baliza de orientação: não se toleram excessos no exercício do poder, mas, simultaneamente, o poder deve atuar positivamente, em favor do cidadão, que não pode estar desprotegido em seu cotidiano. Se o instituto do plea bargaining à brasileira viesse a observar esses limites de orientação, ele poderia ser considerado como ajustado ao modelo de processo penal brasileiro. E não importa o rótulo que se lhe dê. Do contrário, se viesse nos moldes hoje praticados nos Estados Unidos, com penas elevadíssimas, correspondentes, por vezes, à prisão perpétua e até mesmo pena de morte, somado ao poder exacerbado do promotor, que pode inclusive barganhar imputações, ele não seria considerado ajustado ao sistema processual penal brasileiro. E, repita-se, não interessa se ele será chamado de "acusatório" ou "inquisitório", mas sim, se a maneira pela qual vem regrado se ajusta ao plano constitucional interno, ou seja, ao direito interno do Brasil.

\section{Considerações Finais}

Com a abordagem do contexto histórico em que se deu o caso das bruxas de Salem e com o detalhamento de como foram conduzidos os julgamentos - com pressão pela confissão em troca da liberdade, somado a práticas de tortura, em moldes similares ao que se produzia na Europa continental -, pode-se dizer que a expressão primitiva do plea bargaining norte-americano tem traços marcadamente considerados pela doutrina contemporânea como predominantemente "inquisitórios".

A história, portanto, prevalece sobre os discursos, e o que se extrai do quanto sucedeu no século XVII, em Massachussetts, é apenas mais uma prova do equívoco que se enfrenta quando se insiste em seguir vinculado a uma, historicamente, falsa dicotomia dos sistemas em "acusatório" e "inquisitório". A origem "inquisitória" do plea bargaining e a sua sobreposição sobre o sistema "acusatório", invalida classificar o sistema processual penal americano como "acusatório”. Essa análise também 
revela a necessidade de não se desmerecer a importância das diretrizes do direito interno e a evolução histórica de cada Estado, em decorrência de suas origens étnicas, usos e costumes. Assim, e considerando que hoje em dia 95\% dos casos naquele país se resolvem pelo plea bargaining, não faz sentido seguir dizendo que o sistema processual penal dos Estados Unidos da América seja "acusatório".

E mais: desconstruído os rótulos que predominam na doutrina em torno desse tema, não faz sentido insistir no emprego da dicotomia dos sistemas processuais penais, em acusatório versus inquisitório, notadamente na discussão da adoção de modelos processuais inspirados no plea bargaining norte-americano. O que se tem, afinal, nos Estados Unidos é o "sistema processual norte-americano", com suas vantagens e desvantagens históricas, mas que atende à realidade daquele país.

Quanto ao Brasil, resta saber se as propostas legislativas obedecerão às diretrizes da Constituição da República de 1988, de proibição de excessos, de um lado, e de proibição de proteção insuficiente, de outro. Assim, o que menos importa é a etiqueta que se dê.

\section{REFERÊNCIAS}

ALSCHULER, Albert W. Plea Bargaining and Its History. Columbia Law Review. Vol. 79, nº 01, p. 01-43, Jan 1979.

ANDERSON. Robert Charles. The great migration. Volume VI. Boston, 2009.

BARKOW, Rachel E. Separation of Powers and the Criminal Law. Stanford Law Review, Stanford, v. 58, n. 4, p. 989-1054, fev. 2006.

BEAUMANOIR, Philippe de. Les Costumes de Beauvoisis. Nouvelle editión, publié d'aprés le manuscrits de la bibiotheque royale. Paris: Jules Renouard, 1842.

BIENER, Friedrich August. Beiträge zu der Geschichte des Inquisitionsprozesses und der Geschworenengerichte. Leipzig, 1827.

BOYER, Paul. NISSENBAUM, Stephen. Salem Possessed: The Social Origins of Witchcraft. Massachussetts: Harvard University Press, 2003.

BROOKS, Rebecca Beatrice. History of the Salem witch trials. In: History of Massachusetts, 2011. Disponível em: http://historyofmassachusetts.org/the-salemwitch-trials/ acesso dia 26 de julho de 2019. 
BURKE, Alafair S. Persecutorial Passion, Cognitive Bias, and Plea Bargaining. Marquette Law Review, 183, vol. 91, Issue 1. Symposium: Dispute Resolution in Criminal Law, article 9, 2007.

DAVID, René. Os Grandes Sistemas do Direito Contemporâneo. Tradução de Hermínio A. Carvalho. São Paulo: Martins Fontes, 2002.

DE BONI, Luis Alberto. Escritos Seletos de Martinho Lutero, Tomás Müntzer e João Calvino. Tradução de Ilson Kayser, Martin N. Dreher, Helberto Michel, Arno F. Steltzer e Sabatini Lalli. Petrópolis: Vozes, 2000.

DELUMEAU, Jean. O Pecado e o Medo: A culpabilização no Ocidente (Séculos 13-18), vol. II. Tradução de Álvaro Lorencini, Bauru, SP: EDUSC, 2003.

CALVINO, João. Série Comentários Bíblicos - Gêneses. Volume 1, Editora: CLIRE, 2018.

CAMARGO DE CASTRO, Ana Lara. Plea Bargain: resolução penal pactuada nos Estados Unidos. Belo Horizonte: D’Plácido, 2019.

CARBASSE, Jean-Marie. Histoire du droit penal et de la justice criminelle, $2^{a}$ editión refondue. Paris: Presses Universitaires de France, 2009.

CARMIGNANI, Giovanni. Teoria delle leggi della sicuritezza sociale. Tomo IV, Pisa: Fratelli Nistri, 1832.

CARRARA, Francesco. Programma del Corso di Diritto Criminale, Parte Generale. Vol. II, 9ª ed., Firenze: Casa Editrice Libraria “Fratelli Cammelli”, 1902.

CONDÉ, Maryse. Eu, Tituba - bruxa negra de Salem. Rio de Janeiro: Rosa dos Tempos, 2019.

DEZZA, Ettore. Accusa e Inquisizione nell'Esperienza Italiana Contemporanea. In: NEGRI, Daniele e PIFFERI, Michele (org.) Diritti Individuali e Processo Penale nell'Italia Repubblicana. Materiali dall'incontro di studio Ferrara, 12-13 novembre 2010. Per la storia del pensiero giuridico moderno, 93, Milano: Giuffré Editore, 2011, pp. 101-116.

ESTADOS UNIDOS DA AMÉRICA. The Lawes and Liberties of Massachusetts. In: Online Library of Liberty, 1647. Disponível em https://oll.libertyfund.org/ pages/1647-laws-and-liberties-of-massachusetts, acesso em 13 de abril de 2020.

ESTADOS UNIDOS DA AMÉRICA. United States - Mass, 95 (1804), Commonwealth v. Bettis. In: Caselaw Acess Project. Harvard Law School. Disponível em: <https://cite.case.law/mass/1/95/>. Acesso em: 29 dez. 2019. 
FEELEY, Malcolm M. Plea Bargaining and the structure of the criminal process. The Justice System Journal, v. 7, n. 3, p. 338-354, January,1982.

FONSECA, Carlos da. Deus está do nosso lado: excepcionalismo e religião nos EUA. Rio de Janeiro: artigo Scielo, maio 2006.

ESMEIN, Adhemar. Histoire de la procédure criminelle en France: et speciélment de la procédure inquisitoire depuis le XIII siecle jusqu'a nos jours. Paris: L. Larose et Forcel Libraires-Editeurs, 1882.

FISCHER, George. Plea Bargaining's Triumph: a history of plea bargaining in America. Stanford, California: Stanford University Press, 2003.

GANDINUS, Albertus. Strafrecht der Scholastik. Von KANTOROWICZ, Hermann U., Berlin: J. Guttentag, 1907.

GARLATI, Loredana. Per um storia del processo penale: le pratiche criminali. Rivista italiana di storia del diritto, vol. LXXXIX, 2016, pp. 71-109.

GILISSEN, John. Introdução Histórica ao Direito. $4^{\mathrm{a}}$ ed., tradução de A.M. Hespanha e L. M. Macaísta Malheiros. Lisboa: Fundação Calouste Gulbenkian, 2003.

GLOECKNER, Ricardo Jacobsen. Um “novo” liberalismo processual penal autoritário? In: GLOECKNER, Ricardo Jacobsen (org.). Plea Bargaining. São Paulo: Tirant lo Blanch, 2019, p. 177-190.

GRIFFITHS, Megan Rose. Radicals, conservatives, and the Salem witchcraft crisis: Exploiting the fragile communities of colonial New England. Tese. Leiden University, 2017. Disponível em https://openaccess.leidenuniv.nl/bitstream/ handle/1887/49589/MeganGriffithsMAThesis.pdf?sequence=1, acesso em 11 de abril de 2020 .

GRINOVER, Ada Pellegrini. A Iniciativa Instrutória do Juiz no Processo Penal Acusatório. Revista Brasileira de Ciências Criminais, ano 07, n 27, p. 71-79, julhosetembro de 1999.

GUIMARÃES, Rodrigo Régnier Chemim. A Atividade Probatória Complementar do Juiz como Ampliação do Contraditório e da Ampla Defesa no Novo Processo Penal Brasileiro. Tese. Curitiba: UFPR, 2015, disponível em https://acervodigital. ufpr.br/bitstream/handle/1884/41025/R\%20-\%20T\%20-\%20RODRIGO\%20 REGNIER\%20CHEMIM\%20GUIMARAES.pdf?sequence=2\&isAllowed=y, acesso em 09 de janeiro de 2020.

HÉLIE, Faustin. Traité de l'instruction criminelle ou Théorie du Code d'Instruction Criminelle. Premiére partie. Histoire et théorie de la procédure criminelle. Paris: Charles Hingray Libraire-Editeur, 1845. 
KELLY, John M. Uma Breve História da Teoria do Direito Ocidental. Tradução de Marylene Pinto Michael. São Paulo: Martins Fontes, 2010.

LANGBEIN, John H. Torture and Plea Bargaining, The University of Chicago Law Review, Chicago, v. 46, n. 3, p. 03-22, 1978.

LANGER, Maximo. Dos Transplantes Jurídicos às Traduções Jurídicas: a globalização do plea bargaining e a tese da americanização do processo penal. Delictae, vol. 2, no 3, p. 19-115, julho-dezembro de 2017. https://doi.org/10.24861/25265180.v2i3.41

LOPES JR. Aury; PACZEK, Vitor. Plea Bargaining no projeto "anticrime": remédio ou veneno? In: GLOECKNER, Ricardo Jacobsen (org.). Plea Bargaining. São Paulo: Empório do Direito e Tirant Lo Blanch, 2019, pp. 149-174.

MECCARELLI, Massimo. El proceso penal como lugar de determinación de la justicia. Algunas aproximaciones teóricas en la época del ius commune, In: GALAN LORDA, Mercedes (Directora), Gobernar y administrar justicia: Navarra ante la incorporación a Castilla. Navarra: Tompsom Reuters, Aranzadi, 2012, pp. 307-323.

MIRANDA COUTINHO, Jacinto Nelson de; MURATA, Ana Maria Lumi Kamimura. Plea bargaining à brasileira. Boletim Ibbcrim, n 317, abril de 2019.

MITTERMAIER, Carl Joseph Anton. Tratado da Prova em Matéria Criminal. Tradução para o francês da $3^{\mathrm{a}}$ edição (1848), de C.A. Alexandre e para o português de Herbert Wüntzel Heinrich. Campinas: Bookseller, 1997.

MORAIS, Gabriela de Souza. Os processos de Salem: uma breve análise da sua historiografia, memórias e representações. Curitiba: Cadernos de Clio, 2015.

PESSINA, Enrico. Storia delle leggi sul procedimento penale. Napoli: Dott. Pirro Pirrone Editore, 1912.

PIERANGELLI, José Henrique, Processo Penal: evolução histórica e fontes legislativas. Bauru: Jalovi, 1983.

RAUXLOH, Regina. Plea Bargaining in National and International Law. New York: Routledge, 2014.

ROACH, Marilynne K. The Salem Witch Trials. A day-by-day chronicle of a Community under siege. New York: Taylor Trade Publishing, 2004.

ROACH, Marilynne K. Six Women of Salem. The untold story of the accused and their accusers in the Salem Witch Trials. Boston: Da Capo Press, 2013. 
RONCO. Alessandra. Il processo penale nella legislazione tardo imperiale. Tese. Universidade de Padova, Itália, 2008.

ROSENTHAL, Bernard (General Editor). Records of the Salem Witch-Hunt. New York: Cambridge University Press, 2014.

SBRICOLI, Mario. "Vidi Communiter Observari”. L'emerzione di un ordine penale pubblico nelle città italiane del secolo XIII. In: Quaderni Fiorentini, XXVII. Centro studi per la storia del pensiero giuridico moderno. Firenze: Università degli Studi di Firenze, 1998, pp. 231-268

SCHÜNEMANN, Bernd. Crítica al modelo norteamericano de processo penal. In: SCHÜNEMANN, Bernd. Obras. Tomo II. Colección Autores de Derecho Penal. DONNA, Edgardo Alberto (Director), Buenos Aires: Rubinzal-Culzoni Editores, 2009, pp. 427-450.

SOUBBOTNIK, Michael A. Poder, autoridade e codificação das leis na "Cidade na Colina”: a Baia do Massachusetts entre 1630 e 1648. Université Paris-Est-UPEM, 2013, vol.30.

STITH, Kate. The Arc of Pendulum: Judges, Prosecutors, and the Exercise of Discretion. Yale Law School Legal Scholarship Repository, New Haven, $\mathrm{n}^{\circ}$ 117, p. 1420-1497, 2008.

UPHAM, Caroline E. Salem Witchcraft in ouline. $2^{\circ}$ ed. Massachussetts: Duke University Library, 1891.

VALLERANI, Massimo. Procedura e giustizia nelle città italiane del basso medioevo (XII-XIV secolo). In: CHIFFOLEAU, Jacques; GAUVARD, Andrea Zorzi (org.). Pratiques Sociales et Politiques Judiciaires dans les Villes de L'Occident à la Fin du Moyen Age. Publications de l'École française de Rome, 2007, pp. 439-494.

VASCONCELLOS, Vinícius Gomes de. Barganha do Processo Penal e o autoritarismo "consensual" nos sistemas processuais penais: a Justiça negocial entre a patologização do acusatório e o contragolpe inquisitivo. Revista dos Tribunais, 953, março de 2015, pp. 261-279.

WATSON, Duncan. The Attorney General's Guidelines on Plea Bargaining in Serious Fraud: Obtaining Guilty Pleas Fairly? The Journal of Criminal Law. Vol. 74, Edição 1, p. 77-90, fevereiro de 2010.

WOODWARD, W. Elliot. Records od Salem witchcraft - copied from the original documents. Vol. II. Roxbury, Massachussets: Privately printed for W. E. Woodward, 1864. Disponível em https://babel.hathitrust.org/cgi/pt?id=nyp.33433005881358\&view=1up\&seq=15, acesso em 16 de abril de 2020 . 


\section{Informações adicionais e declarações dos autores (integridade científica)}

Declaração de conflito de interesses (conflict of interest declaration): os autores confirmam que não há conflitos de interesse na realização das pesquisas expostas e na redação deste artigo.

Declaração de autoria e especificação das contribuições (declaration of authorship): todas e somente as pessoas que atendem os requisitos de autoria deste artigo estão listadas como autores; todos os coautores se responsabilizam integralmente por este trabalho em sua totalidade.

- Sarah Gonçalves Ribeiro: projeto e esboço inicial da análise histórica do caso das Bruxas de Salem como inerente ao sistema inquisitório (conceptualization), coleta e análise de dados do caso das Bruxas de Salem e da origem da colonização norte-americana (data curation), levantamento bibliográfico (investigation), redação (writing - original draft), participação ativa nas discussões dos resultados (validation), revisão crítica com contribuições substanciais (writing - review and editing), aprovação da versão final.

- Rodrigo Régnier Chemim Guimarães: projeto e esboço inicial de vincular a discussão do caso das Bruxas de Salem à demonstração da necessidade de se repensar a vinculação dicotômica dos sistemas, análise das origens dos discursos na doutrina de processo penal do século XIX e sua base nos práticos do século XIII, com análise crítica do dualismo entre "acusatório" e "inquisitório" com pretensões de pureza científica (conceptualization), desenvolvimento da metodologia (methodology), coleta e análise de dados tanto dos sistemas quanto, em parte, das fontes primárias do caso das Bruxas de Salem (data curation), levantamento bibliográfico (investigation), revisão bibliográfica (investigation), redação (writing - original draft), participação ativa nas discussões dos resultados (validation), revisão crítica com contribuições substanciais (writing - review and editing), aprovação da versão final. 
Declaração de ineditismo e originalidade (declaration of originality): os autores asseguram que o texto aqui publicado não foi divulgado anteriormente em outro meio e que futura republicação somente se realizará com a indicação expressa da referência desta publicação original; também atestam que não há plágio de terceiros ou autoplágio.

\section{Dados do processo editorial}

(http://www.ibraspp.com.br/revista/index.php/RBDPP/about/editorialPolicies)

- Recebido em: 10/01/2020

- Controle preliminar e verificação de plágio: $19 / 01 / 2020$

- Deslocamento ao V6N2 e aviso autores: 19/01/2020

- Avaliação 1: 20/01/2020

- Avaliação 2: 20/01/2020

- Avaliação 3: 28/01/2020

- Decisão editorial preliminar: 10/04/2020

- Retorno rodada de correções 1: 16/04/2020

- Decisão editorial preliminar 2: 06/05/2020

- Retorno rodada de correções 2: 06/05/2020

- Decisão editorial final: 12/05/2020

\section{Equipe editorial envolvida}

- Editor-chefe: 1 (VGV)

- Revisores: 3 


\section{COMO CITAR ESTE ARTIGO:}

RIBEIRO, Sarah; CHEMIM, Rodrigo. O caso das Bruxas de Salem e a origem do plea bargaining norte-americano: contrapondo o entendimento dicotômico dos sistemas processuais penais. Revista Brasileira de Direito Processual Penal, Porto Alegre, vol. 6, n. 2, p. 835-872, mai./ago. 2020. https://doi.org/10.22197/rbdpp.v6i2.323

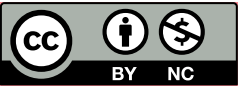

Esta obra está licenciada com uma Licença Creative Commons Atribuição-NãoComercial 4.0 Internacional. 